\title{
The Effect of Telepresence, Social Presence and Involvement on Consumer Brand Engagement: An Empirical Study of Non-Profit Organizations
}

\author{
Raed Algharabat \\ The School of Business Department of Marketing, \\ The University of Jordan, Amman, Jordan \\ r.gharabat@ju.edu.jo \\ Nripendra P. Rana* \\ School of Management \\ Swansea University \\ Bay Campus, Fabian Way \\ Swansea, SA1 8EN, UK \\ Tel: +44(0) 1792295179 \\ nrananp@gmail.com \\ Yogesh K. Dwivedi \\ School of Management \\ Swansea University \\ Bay campus, Fabian Way \\ Swansea, SA1 8EN, UK \\ y.k.dwivedi@swansea.ac.uk \\ Ali Abdallah Alalwan \\ Amman College of Banking and Financial Sciences \\ Al-Balqa' Applied University, Amman, Jordan \\ alwan.a.a.ali@gmail.com \\ Zainah Qasem \\ Marketing Department \\ Jordan University Business School \\ The University of Jordan, Amman, Jordan \\ Z.qasem@ju.edu.jo \\ * Corresponding author
}

\begin{abstract}
Although there are several marketing implications that have been considered in the context of social media marketing, less attention has been paid to the influence of antecedents of consumer brand engagement (telepresence, social presence and involvement) and their consequences for non-profit organizations. Thus, the main purpose of current research is to examine the influence of telepresence, social presence and involvement on consumer brand engagement (CBE) (second-order), which in turn affects electronic word of mouth and willingness to donate. To test the proposed model, this paper used social media platforms. We employed a Facebook page that presents non-profit organizations (brands) using a sample of nonstudents.We found that telepresence, social presence and involvement positively impact $\mathrm{CBE}$, which in turn impacts electronic word of mouth and willingness to
\end{abstract}


donate. The findings of our research demonstrate how CBE is formed in this particular context and what outcomes are to be expected, with important implications for both marketing theory and practice.

Keywords: telepresence, social presence, involvement, consumer brand engagement, non-profit organization, Jordan

\section{Introduction}

The notion of engagement has received a lot of attention recently. However, the definition of this construct varies among scholars (Bolton 2011; Karson and Fisher, 2005; Passikoff et al., 2007; Verhoef, Reinartz, and Krafft 2010). Within the context of social media platforms, consumer/brand relationships appear significant (Bolton and Saxena-Iyer, 2009; Malthouse and Hofacker 2010). Therefore, the notion of consumer brand engagement, which is related to consumers' interactive brand-related dynamics (Brodie, Hollebeek, Juric and Ilic, 2011), attracted the attention of previous researchers (e.g. Calder etal., 2009; Van Doorn et al., 2010).

However, despite previous attempts to conceptualize the notion of engagement, this paper focuses on the notion of consumer brand engagement (CBE), which was developed by Hollebeek, Glynn and Brodie (2014) by expanding its antecedent (i.e. involvement) and consequences (brand loyalty) on social media platforms for nonprofit organizations. Our efforts come in accordance with the Marketing Science Institute (MSI, 2014), which recommends scholars conduct more research in the area of consumer engagement (CE). With this research we aim particularly to answer the call of MSI (2014, p.4), under the Tier 1 Research Priority of "Understanding Customers and Customer Experience," which asks "How does social media and other marketing activities create engagement?" As Islam and Rahman (2016) assert, research on consumer engagement in social network sites is still underexplored and requires deeper investigation.

Therefore, despite the sole attempt of Mollen and Wilson (2010) to link telepresence with CBE for online websites, which was not empirically tested, there is not any study, to the best of the authors' knowledge that has examined the impact of social presence in the CBE setting. Therefore, this research has its own contributions. For instance, within the context of social media platforms, (i) there is, still, a belief that CBE is not linked to telepresence and social presence, and (ii) there is also a belief that existing research does not support building $\mathrm{CBE}$ (antecedents and their consequences) at non-profit organizations. Therefore, the primary aim of this current research is to fill this gap, within the non-profit context, by investigating the antecedents of $\mathrm{CBE}$ and their consequences over the platform of social media applications as well as to provide answers to two main critical questions:

1) Within social media platforms, how do involvement, telepresence and social presence impact CBE?

2) Within social media platforms, how does CBE impact word of mouth, and willingness to donate?

This paper is organized as follows. First, we explain the existing literature on CBE, telepresence, social presence and involvement. Second, the theoretical framework for 
the current study is discussed. Third, the research methodology and results are discussed. Finally, we conclude with theoretical, managerial implications, directions for future research and limitations.

\section{Theoretical Background}

\section{Research Model and Hypotheses}

As presented in Figure 1, the proposed conceptual model, research hypotheses and associated factors - telepresence, social presence, involvement, consumer brand engagement, electronic word of mouth and willingness to donate-are presented in line with what has been discussed in the prior studies.

Figure 1. Proposed research model

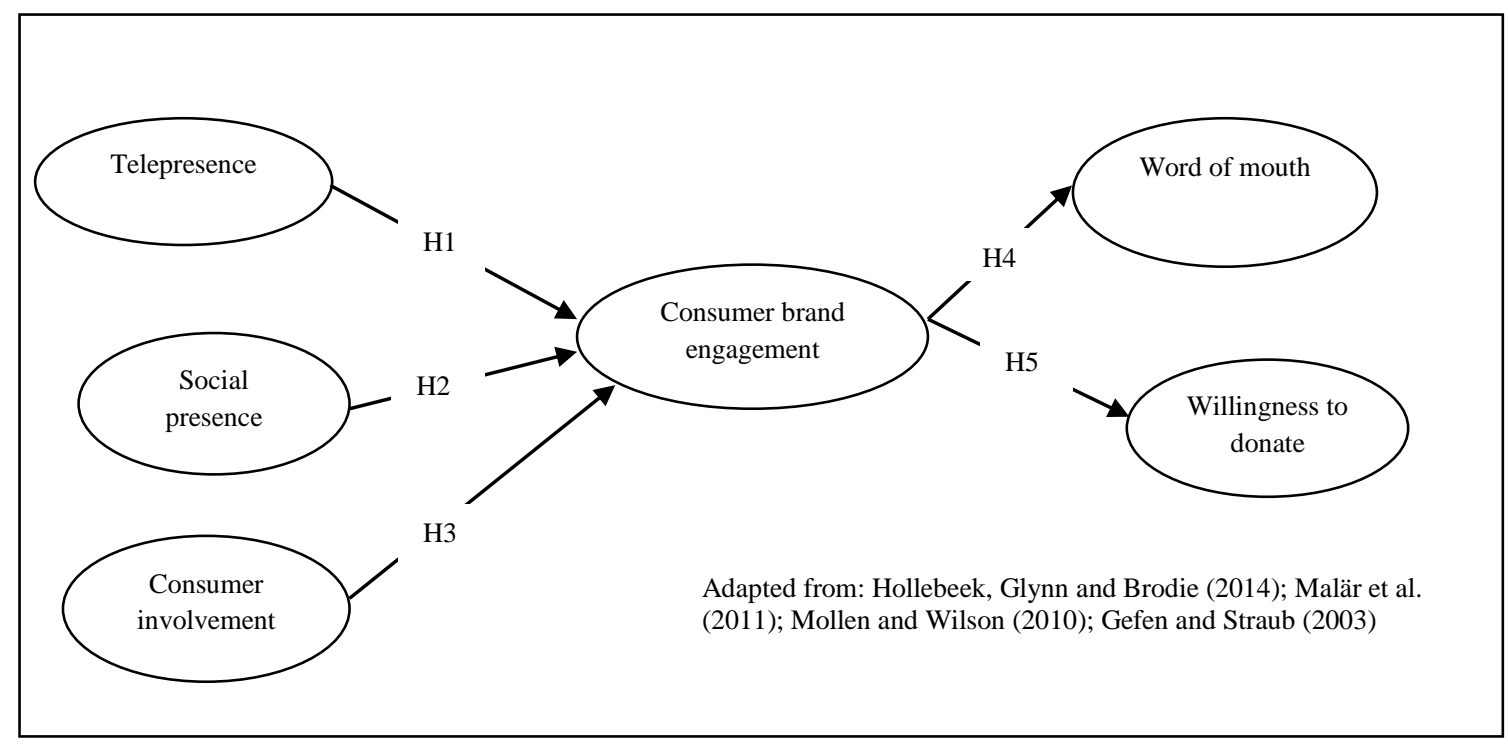

\section{Consumer Brand Engagement}

The notion of engagement has been discussed from diverse academic perspectives (i.e. psychology and organizational behavior) and it has been reflected in the marketing literature recently (Brodie et al., 2011; Hollebeek et al., 2014, 2017; Kunz et al., 2017; Leeflang 2011; O'Brien et al., 2015). The emerging literature on engagement from marketing literature (e.g., Alalwan et al., 2017a; Avnet and Higgins 2006a, 2006b; Pham and Avnet 2009; Schau, Muñiz, and Arnould 2009) posits that engagement is a promising concept, which is expected to enhance the power of consumer behavior outcomes such as brand loyalty.

However, previous studies that have addressed CBE are still limited (e,g. Algesheimer, Dholakia, and Herrmann, 2005; Brodie et al., 2013; Dwivedi, 2015; Hollebeek, 2011a, b; Hollebeek et al., 2014; Keller, 2013; Mollen and Wilson, 2010; Sprott, Czellar and Spangenberg, 2009; Vivek, Beatty, Dalela and Morgan, 2014; Leckie, Nyadzayo and Johnson, 2016). The following describes the development of the notion of $\mathrm{CBE}$ in marketing literature. First, within the offline context, Algesheimer et al. (2005), employed the notion of brand community engagement, 
which centers on the positive impact of identifying brand community intrinsic motivation of consumers to be engaged and involved with community members. The authors posit that brand community engagement is a multidimensional construct comprised of utilitarian, hedonic and social factors. Second, within the online context, Hollebeek (2011a) adopted the notion of CBE and illustrated that the notion of engagement has derived the interest of a good number of researchers in the related area. However, the author posits that this notion is underexplored. Therefore, the author aims to bridge this gap by comparing relevant studies over different disciplines and in marketing. Hollebeek (2011a, p.790) defines CBE as "the level of an individual customer's motivational, brand-related and context-dependent state of mind characterized by specific levels of cognitive, emotional and behavioral activity in direct brand interactions." Furthermore, the author, theoretically, proposed that involvement should be an antecedent for $\mathrm{CBE}$ and that relationship quality (i.e. customer satisfaction, commitment and trust) is the main consequence for CBE and vice versa. The author also proposed that relationship quality leads to customer loyalty.

After reviewing the relevant literature on consumer engagement, Hollebeek (2011b, p.555) conducted qualitative research to define CBE. The author integrated three theories to explain the notion of CBE: relationship marketing, service-dominant logic perspectives and social exchange theory. The author defined CBE as "the level of a customer's cognitive, emotional and behavioral investment in specific brand interactions."'The author identified three themes for CBE: immersion, passion and activation.

Sprott et al. (2009, p.92), based on a uni-dimensional construct (i.e. emotional), center their efforts on developing a scale related to brand engagement in self-concept. The authors define brand engagement based on a set of brands, rather than on a specific one, as 'an individual difference representing consumers' propensity to include important brands as part of how they view themselves."Furthermore, the authors posit that brand engagement impacts brand identification. Phillips and McQuarrie (2010) proposed the notion of advertising engagement and define it as "modes of engagement" as routes to persuasion. The authors measured engagement based on a multidimensional construct: immerse, feel, identify and act. Mollen and Wilson (2010, p.5) centered their effort on measuring brand engagement within the context of websites. The authors define engagement as "the cognitive and affective commitment to an active relationship with the brand as personified by the website or other computer-mediated entities designed to communicate brand value." Furthermore, the authors measured engagement using a multidimensional scale consisting of cognitive, instrumental value (utility and relevance) and experiential value (emotional). The authors argued that telepresence is the main antecedent of engagement and that optimal consumer attitude and behavior are the main consequences.

Moreover, marketing researchers have adopted different approaches to conceptualize engagement (Hollebeek et al., 2014). For instance, Brodie et al. (2011, p.258) define engagement based on consumer engagement as "a motivational state that occurs by virtue of interactive, co-creative customer experiences with a focal agent/object (e.g. a brand) in focal brand relationships." Furthermore, Brodie et al. (2011) posit that customer engagement definition should reflect five themes. The first theme relates to interactive consumer experiences (van Doorn et al., 2010). The second theme reflects 
the intensity of the motivational state (Nolan et al., 2007). The third theme of engagement reflects wider, active and associative processes (Bowden, 2009). The fourth theme is related to the multidimensional (cognitive, affective and behavioral) aspect of consumer engagement (Patterson et al., 2006). The fifth theme distinguishes the central role of consumer engagement in the process of relational exchange. The authors differentiate between engagement antecedents (e.g. participation and involvement) and consequences (e.g. trust, connection, loyalty, commitment, satisfaction, empowerment and emotional bonding).

Based on the themes of Brodie et al. (2011), Brodie et al. (2013, p.107) developed a working definition for consumer engagement, based on consumer engagement within the brand community. The authors claim that "consumer engagement in a virtual brand community involves specific interactive experiences between consumers and the brand, and/or other members of the community." The authors posit that consumer engagement is at the heart of the process of relational exchange and it is a multidimensional construct measured via three dimensions: cognitive, emotional and behavioral. Furthermore, the authors illustrated that within the context of brand community other relational concepts considered either antecedents and/or consequences of engagement.

Brodie et al. (2013) assert that this working definition parallels previous research (Bowden, 2009; Hollebeek, 2011a, 2011b; van Doorn et al., 2010) process perspective of defining consumer engagement. However, the authors assert that this working definition is different than other definitions produced by Patterson, Ting, and De Ruyter (2006) and Vivek, Beatty and Morgan (2012). For instance, Vivek et al. (2012, p.133) defined CE as "the intensity of an individual's participation in and connection with an organization's offerings or organizational activities, which either the customer or the organization initiates." Therefore, Vivek et al. (2012) emphasized specific descriptions of consumer engagement (behavioral, cognitive and emotional dimensions). Conversely, Mollen and Wilson (2010) focused on specific online contexts to conceptualize the concept of online brand engagement. Thus, according to the authors, the working definition presents a wider conceptualization of online brand engagement and it provides more context-specific scrutiny.

To that end, Hollebeek et al.'s (2014) study relied on Brodie et al.'s (2013) definition of $\mathrm{CBE}$ and investigated different conceptualizations of engagement. The authors proposed a new definition for CBE as consumer's positively valence cognitive, emotional and behavioral brand-related activity during, or related to, specific consumer/brand interactions. The authors measured CBE as a multidimensional construct consisting of cognitive processing, affection and activation. Therefore, according to Hollebeek et al. (2014), previous research on engagement literature covers: brands, offerings, organizations and organizational activities occurring beyond purchase (Patterson et al., 2006; van Doorn et al., 2010), while consumer engagement and brand engagement often reflect the same scope. According to Hollebeek et al. (2014), the main difference could be illustrated by the nature and dynamics of consumer engagement. For instance, van Doorn et al. (2010) adopt a more organization-centric approach, while Hollebeek et al. (2014) focused on a consumercentric approach. 
Keller (2013) asserts that CBE is related to consumer willingness to invest personal resources. The author illustrates that $\mathrm{CBE}$ is a multidimensional construct comprised of cognition, participation and interaction. According to Dwivedi (2015), CBE leaves the customer in a positive and satisfied state of mind. The author argues that CBE is a multidimensional construct measured by vigor, dedication and absorption. Furthermore, the author outlines consumer product category involvement and brand usage duration as the main antecedents of $\mathrm{CBE}$, which in turn impacts the consequence (loyalty intentions). Vivek et al. (2014) focused on consumer engagement and defined it as the behavioral manifestation toward a brand. The authors measured consumer engagement as a multidimensional construct including three main aspects: attention, participation and social connection.

In the mobile service sector, Leckie et al. (2016) employed the proposition of Hollebeek et al. (2014), which contains three dimensions of CBE: cognitive processing, affection and activation. Indeed, the authors investigated the impact of involvement, participation and self-expressive brand (as the main consequences of $\mathrm{CBE}$ ) on $\mathrm{CBE}$, which in turn impact brand loyalty. Furthermore, the authors find positive indirect impact of involvement on brand loyalty.

Dessart, Veloutsou and Thomas (2016) conducted an inclusive analysis of the prior studies related to consumer engagement. The authors argue that previous studies in this area lack a comprehensive definition and conceptualization of consumer engagement. Furthermore, the authors posit that within this area quite a few studies have adopted a quantitative approach (e.g., Brodie et al., 2013; Dessart et al., 2016; Hollebeek et al., 2014; Leckie et al., 2016). As a conclusion, Dessart et al. (2016) assert that previous studies lacked proper measurement of this notion because they either focused on a single versus multiple engagement foci (i.e., a brand, firm or organization, a brand community, or others), or because they conceptualized consumer engagement to include a context-specific subject and an object. Dessart et al.'s (2016) conceptualization of consumer engagement centers on brand engagement and community engagement. The authors categorized dimensions (and subdimensions) for measuring consumer engagement: affect (enthusiasm and enjoyment), cognitive (attention and absorption) and behavioral (sharing, learning and endorsing).

\section{Telepresence and Consumer Brand Engagement}

Derived from the area of virtual experience (a real or simulated environment in which the perceiver experiences other worlds), the notion of telepresence, which is the sense of being present in a remote environment (Steuer, 1992), has been appeared. Steuer (1992, p.76) suggests that telepresence is "the mediated perception of an environment." Biocca (1992) defined it as users' ability to be psychologically transported into another area (Algharabat and Dennis, 2010c). Therefore, in the context of the current study, telepresence is the perception by non-profit organizations' Facebook fans that they have been, psychologically, transported in the world created by the non-profit Facebook page. Thus, telepresence depends on the medium's ability to simulate users' direct experience of interacting with the products offline.

Previous studies on e-commerce websites (e.g., Coyle and Thorsen, 2001; Klein, 2003; Laurel, 1991; Steuer, 1992) posit that consumer experience could be 
accelerated via the role of virtual reality resulting from telepresence. In addition, these studies have paid attention to the significance of interactivity and vividness as the main antecedents of telepresence. Interactivity refers to the customer's ability to engage in adapting the context and content of the mediated environment in real time. Vividness has been defined by Steuer (1992, p.74) as "the representational richness of a mediated environment as defined by its formal features, which is the way in which an environment presents information to the senses." Therefore, the higher the interactivity and vividness, the higher the telepresence experience. In the same context, Coupey (2000) asserts that vividness is more associated with the extent to which technology is able to make the mediated environment richer and more sensorial. To put it differently, the main technical features of the medium largely reflect the level of vividness.

Within the context of online brand engagement, Mollen and Wilson (2010, p.8) revised the definitions of telepresence and proposed the following definition: "a psychological state of 'being there' in a computer-mediated environment, augmented by focused attention." Therefore, telepresence is characterized by control, involvement, cognitive and emotional arousal that customers could have in the mediated environment as well as perceiving themselves to be submerged (immersed) in such an environment. The authors argue that this definition is synthesizing the previous studies in the area of telepresence (Slater, 1999; Witmer and Singer, 1998). The authors posit that this definition granted the hybridization of flow and telepresence attributes and it does include both of them. Furthermore, Mollen and Wilson (2010) assert that interactivity, flow, telepresence and online brand engagement are related constructs. Notwithstanding, interactivity (defined as two-way communication, controllable and responsiveness, according to Downes and McMillan 2000; Lui and Shrum 2002) is proposed to be an antecedent to telepresence, which in turn is considered an antecedent to engagement. Therefore, Mollen and Wilson (2010) proposed that telepresence positively impacts engagement. Furthermore, flow as an idea associated with telepresence was recommended by both Hollebeek (2011b) and Brodie et al. (2011) to be a key predictor of the consumer's engagement.

The impact of telepresence on product beliefs, attitude toward brand and attitude toward advertising (Coyle and Thorson, 2001; Fiore, Jihyun, and Hyun-Hwa, 2005; Hopkins et al., 2004; Klein, 2003) has been investigated. For instance, Klein (2003) found that both the intensity of customer attitudes and beliefs toward a product (cognitive and affective parts of the $\mathrm{CBE}$ ) are strongly predicted by the role of telepresence. In line with Klein (2003), Hopkins et al. (2004) investigated the impact of telepresence, in a computer-mediated advertising context, on attitude toward brand and attitude toward advertising (cognitive and affective parts of the CBE). The authors find a positive relationship between telepresence, attitude toward brand and attitude toward advertising. Telepresence was noticed by Fiore et al. (2005) to have a positive and causal path with instrumental and experiential values (dimensions of CBE). Mollen and Wilson (2010) proposed the mediation impact of engagement between the relationship of telepresence and consumer attitude and behaviors. The authors relied on Fiore et al.'s (2005) study, which interposes that both instrumental and experiential values (another definition of consumer engagement) mediate the relationship between telepresence and consumer attitudes. Accordingly, telepresence is considered as a key predictor of CBE, as reported by Fiore et al. (2005) and Mollen and Wilson (2010). 
However, for this study we adopted the definition of Steuer (1992, p.75). Steuer (1992) and Biocca (1992) argue that online experience should be reflected by virtual reality in which the user feels present, and experiences telepresence. Thus, within the context of social media platforms, in particular within non-profit organizations' Facebook pages, it is expected that direct consumer online experience is more likely to be simulated by the role of telepresence as mentioned by Coyle and Thorsen (2001), Klein (2003) and Steuer(1992). Drawing on this, we expect that while users interact with a non-profit organization's Facebook page, according to telepresence theory, visitors will be mentally transported to the non-profit offline location. Therefore, telepresence is expected to increase consumer engagement with the brand page of non-profit organizations. Thus, within the context of social media platforms:

H1: There is a positive relationship between telepresence and consumer brand engagement.

\section{Social Presence and Consumer Brand Engagement}

Social presence was conceptualized by Fulk, Schmitz, and Power (1987) as the ability of a medium to let consumers engage with others in terms of being psychologically present. Accordingly, as long as a medium has an adequate degree of social presence, it is more able to transform content related to facial expressions, posture, dress and non-verbal cues. Previous research (Heerink et al., 2008; Lii, 2009; Shin and Choo, 2011) argues that social presence is related to the sense of illusion and feelings of presence of other human beings. Notwithstanding, other research (e.g., Rice and Case, 1983; Yoo and Alavi, 2001) posits that social presence is a psychological process, which centers on warmth. In other words, a medium is perceived as warm if it conveys a feeling of human contact, sociability and sensitivity. Short, Williams, and Christie (1976) posit that social presence is related to human senses in a communication medium. Kreijns et al. (2004) define it based on the level of illusion of physically being with other people. Other scholars (e.g., Straub, 1994; Straub and Karahanna, 1998; Sproull and Kiesler, 1986) assert the ability of social presence to enhance information richness.

According to Gefen and Straub (2003), in a similar way to personal pictures and letters, images and text content posted on a digital medium are largely able to transmit a personal presence. Therefore, language, text and picture scan form a sense of psychological closeness and warmth (Weiner and Mehrabian, 1968), often resulting in enhanced social presence. At the same context, Short et al. (1976) stated that human visual media have more social presence than written media. Dormann (2001) proposes that using social display (i.e. human pictures) enhances the success of e-commerce. Kietzmann, Silvestre, McCarthy and Pitt (2012) posit the positive relationship between social presence and engagement. For Kruikemeier et al. (2013), human interactivity and contact could be accelerated by the role of social presence. Fortin and Dholakia (2005) postulated that the level of functional engagement has a positive relationship to social presence. Therefore, if customers perceive an adequate level of social presence, they are more likely to have positive cognitive, affective and behavioral reactions (Hassanein and Head, 2006; Gefen and Straub, 2003; van der Heijden, 2003). As stated by relevant studies (i.e. Gefen and Straub, 2003; Kumar and Benbasat, 2002), the main characteristics of the interface (e.g. virtual communities, human web, message boards, chats etc.) are very important aspects predicting the 
level of social presence perceived in the targeted website. Algharabat and Shatnawi (2014) assert that social presence increases the quality of commercial websites. Cyr, Hassanein, Head and Ivanov (2007) report a positive relationship between social presence and enjoyment. Accordingly, social presence is considered one of the main antecedents of consumer engagement (Algharabat and Shatnawi, 2014; Mollen and Wilson, 2010). Within the online social media context, Yap and Lee (2014) suggest that social presence should have an influence on CBE. Tafesse (2016) asserts that perceived social presence positively impacts CBE. Pongpaew et al. (2017) conducted a qualitative study on the relationship between social presence and $\mathrm{CBE}$, finding that corporate Facebook pages with high social presence functions enhance CBE dimensions (cognitive, emotional and behavioral).

In the social media context, it could be proposed that both social presence and telepresence are more likely to be attained by capturing a feeling of human warmth and sociability. This could be reached by accelerating the user's ability to imagine and socially interact as they would in the physical world. Drawing on this, we expect that while consumers interact with the non-profit organization Facebook pages (the brand), the brand should provide consumers with a sense of human warmth and sociability to increase consumer engagement with the non-profit organization Facebook page. Thus, within the context of social media platforms:

$\mathrm{H}$ 2: There is a positive relationship between social presence and consumer brand engagement.

\section{Consumer Brand Involvement and Consumer Brand Engagement}

Bowden (2009) defines involvement as an internal state of arousal, which can be used to reflect an ongoing concern by the customer toward a product based on the perceived importance and/or general interest in the purchase process. Furthermore, previous research (Mittal 1995; Zaichkowsky, 1985, 1994) defines consumer involvement as an individual's level of interest and personal relevance in relation to a focal object/decision in terms of one's basic values, goals and self-concept.Based on Thomson, MacInnis, and Park's (2005) definition of involvement as "a state of mental readiness that typically influences the allocation of cognitive resources to a consumption object, decision, or action," Mollen and Wilson (2010) posit that researchers should distinguish between the notions of engagement and involvement. The authors assert that involvement requires a consumption object (e.g. product category), while engagement does not. Further, the authors posit that involvement requires in this context a "brand personified by the website." The authors illustrate that engagement is greater than involvement because it is related to an active relationship with the brand as personified by the website. Therefore, the involvement construct refers to a more passive allocation of mental resource. On the other hand, engagement requires the fulfillment of cognitive, affective and behavioral aspects while involvement is commonly associated with instrumental value.

Zaichkowsky (1985) asserts the positive relationship between involvement and feeling toward the brand. Beatty and Smith (1987) posit the positive relationship between involvement with the focal brand and engagement with the external search about the brand. Vivek et al. (2012) theoretically proposed that involvement and consumer participation are the main antecedents of consumer engagement. Brodie et 
al. (2011) and Bowden (2009) assert that involvement and participation (as relational constructs) should be considered as antecedents to create consumer engagement. Furthermore, Hollebeek (2011, a, b) theoretically posits that involvement is a main antecedent of CBE. Wirtz et al. (2013) investigate the impact of involvement on online brand communities. The authors find that involvement with the brand intensifies the positive impact on online brand engagement. Hollebeek et al. (2014) find a positive relationship between consumer involvement and CBE (with its three dimensions: cognitive processing, affection and activation). Dwivedi (2015) asserts that involvement is a main antecedent of CBE. Within the mobile phone context, Leckie et al. (2016) found that involvement has a positive impact on CBE dimensions (positive with cognitive processing, affection and activation). Hepola et al. (2017) find a positive impact of personal involvement on CBE dimensions (cognitive processing, affective and activation). Thus, within the context of social media platforms:

H3: There is a positive relationship between involvement and consumer brand engagement.

\section{Consumer Brand Engagement, Word of Mouth and Willingness to Donate}

Non-profit organizations Facebook pages (the brand) are reliant on fundraising and donations in order to successfully operate (Seitel, 2011). Previous research (e.g. Bowden, 2009; Hollebeek, 2011b; Hollebeek et al., 2014) asserts the positive relationship between CBE and customer loyalty. For example, Bowden (2009) considers consumer engagement as a superior antecedent of consumer loyalty. Cheung et al. (2011) assert the positive relationship between consumer engagement (e.g. consumer willingness to invest physical, cognitive and emotional effort in an online social media platform) and propensity to spread word of mouth (Sivadas and Jindal, 2017). Kumar et al. (2010) stated the significant relationship between consumer engagement and consumer loyalty and word of mouth. Vivek et al. (2012) theoretically proposed that retention, positive word-of-mouth communication and loyaltyare potential consequences of consumer engagement. Leckieet al. (2016) found a positive relationship between CBE dimensions (affection and activation) and brand loyalty. Dwivedi et al. (2016) assert that spreading positive electronic word of mouth is one of the significant consequences of CBE. Halaszovich and Nel (2017) posit the positive relationship between CBE dimensions (affection and activation) and word of mouth. In the current study, consumers' liking of a non-profit organization Facebook page reflects their brand engagement (Phua and Ahn, 2016). Therefore, the "Like" of the non-profit page results in spreading positive opinions regarding the fan page (Chang et al., 2015). Accordingly, for the purposes of this research, we propose two of the consequences of $\mathrm{CBE}$, namely word of mouth and willingness to donate. Drawing on this, we expect that while consumers interact with the non-profit organization Facebook page (the brand) this will result in increasing the probability of its members spreading positive word of mouth and being willing to donate. Thus, within the context of social media platforms:

H4: There is a positive relationship between consumer brand engagement and word of mouth.

H5: There is a positive relationship between consumer brand engagement and willingness to donate. 


\section{Research Methodology}

\section{Data Collection}

A total of 400 valid responses were captured in the current study. Those 400 respondents are Jordanian consumers who served as Facebook Page fans for nonprofit organizations related to charity foundations, which inform visitors about their activities and seek donations. The fans were allowed to freely act and respond to the targeted Facebook page (i.e. liking, commenting or sharing it with their own networks). Therefore, we chose non-profit organizations Facebook pages to represent the brands and as a tool for consumer engagement. We used a non-probability (nonstudents) convenience sampling technique due to the difficulty of finding an inclusive and updated list of the online donors to non-profit organizations in Jordan (Algharabat et al., 2017; Dwivedi et al., 2006). The empirical study and data collection were conducted in Jordan. Thus, as the native language for the people in Jordan is Arabic, the back-translation method recommended by Brislin (1986) was applied. Then the translated questionnaire was subjected to a pre-test with a small sample of nonstudents in Jordan.

We chose non-profit organizations because of the high level of competition in this sector; thus, non-profit organizations seem to have significant interest in adopting methods and tools that could help them attract people's attention and gain their support in terms of donation. Therefore, there is always a need to fully understand the customer-brand relationship to guarantee the success of non-profit organizations, and investigating the antecedents and consequences of CBE is important. We collected the data using online tools in order to maximize response rates (Deutskens, De Ruyter, and Wetzels, 2006). To do so, we asked the most reputable non-profit organizations to include our survey on their Facebook pages. We used a filtering question by asking the respondents whether they follow the news of their preferred non-profit organization regularly. If the respondent's answer was yes, we asked them to think about their most favorable non-profit organization Facebook page (the brand), if they have more than one, which they follow and admire. The selected brand name of the non-profit organization was then auto-filled for the remaining questions relating to the brand in the survey (Leckie et al., 2016). Half of the respondents of the current sample study were male and the other half were female; the vast majority of respondents (99\%) were aged 24 to 50. A total of 22.7, 33.5, 29.5, 13.3 and 1 percent of the respondents were between 24 and 30, 31 and 37, 38 and 43, 43 and 50 and above 50 years, respectively. Further, the respondents indicated that they had varied relationship duration with the non-profit Facebook pages as follows: less than 1year (15.1 percent), between 1year and 3 years (24.9 percent), between 4 and 5 years (35.1 percent) and over 5 years (24.9 percent). Roughly $100 \%$ of the sample reported that they have had prior experience with online donation. A non-response bias test was applied as suggested by Armstrong and Overton (1977). The yield results indicated that there is no significant difference between respondents $(p>0.05)$ regarding telepresence, social presence, involvement, consumer brand engagement, word of mouth and willingness to donate.

\section{Construct operationalization}


Respondents were informed that their participation in completing the given questionnaire was part of a study aiming to examine the main factors predicting CBE and the consequences for non-profit organizations' Facebook pages. The five-point Likert scale ranging from "strongly disagree" to "strongly agree" was adopted to measure the main constructs items. As presented in Appendix 1, all constructs and their respective items were captured and supported from the prior literature in the relevant area of interest.

\section{Analysis and Results}

Two statistical tools: SPSS 17.0 and AMOS 17.0 were used to examine both the measurement model (i.e. confirmatory factor analyses) and structural model (i.e. the proposed conceptual model and research hypotheses).

\section{Measurement Models}

We used AMOS 17.0 to evaluate the measurement model properties for the proposed model. Therefore, we treated CBE (the focal construct) as a second-order construct, while its three dimensions [cognitive processing (CP), affection (AF) and activation (AC)], which represent first-order factors, were measured through their own observed factors (items). The second-order CFA model fit was tested and noticed to have an adequate level of model fitness due to the fact that all indices captured values within their threshold levels $\left(\chi^{2}=77.808, \mathrm{df}=29\right.$; and $\left.\chi^{2} / \mathrm{df}=2.683\right)$, comparative fit index $[\mathrm{CFI}]=0.977$, goodness-of-fit index $[\mathrm{GFI}]=0.963$, Tucker-Lewis index $[\mathrm{TLI}]=$ 0.964, incremental fit index $[\mathrm{IFI}]=0.977$, and root mean square error of approximation $[\mathrm{RMSEA}]=0.065), \mathrm{AGFI}=0.929$ (Figure 2 and Table 1$)(\mathrm{Hu}$ and Bentler, 1999). At $\alpha=0.05$ level, all items were also able to significantly load on their latent first-order constructs. Further, as presented in Figure 2 and Table 1, the firstorder constructs $\mathrm{CP}, \mathrm{AF}$ and $\mathrm{AC}$ all have a significant coefficient value with $\mathrm{CBE}$ as a second-order construct. Table 2 shows discriminant validity through the Pearson correlation between constructs against the square roots of average variance extracted (AVE) across diagonal, all of which proved to be acceptable.

Figure 2. Second-order factor analysis of CBE dimensions 


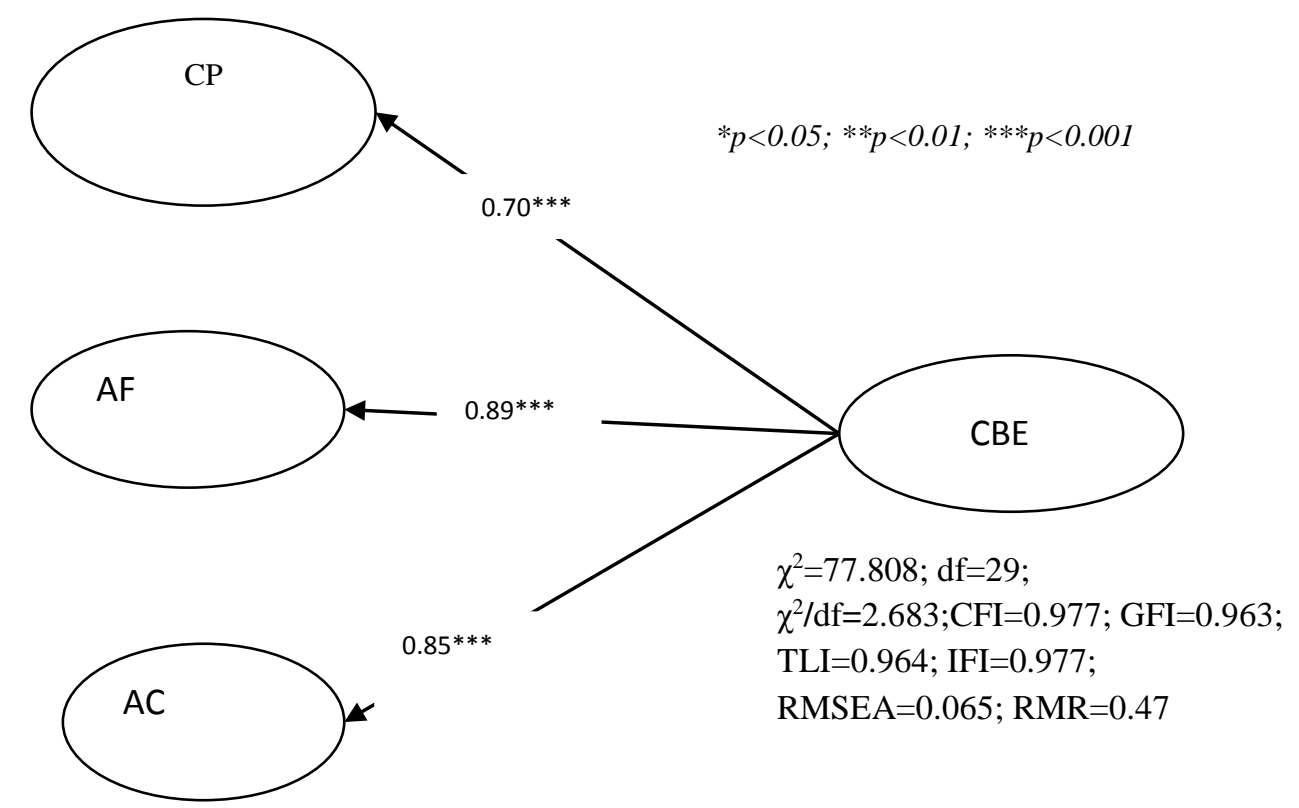

Table 1. Results of the CFA: Using a second-order conceptualization of CBE

\begin{tabular}{|c|c|c|c|c|c|c|c|c|}
\hline Indicator & Direction & Construct & $\begin{array}{c}\text { Standardized } \\
\text { Loading }\end{array}$ & SE & t-value & $\mathrm{P}$ & CR & $\begin{array}{c}\mathrm{AVE} \\
\%\end{array}$ \\
\hline CP1 & $\leftarrow$ & $\mathrm{CP}$ & 0.80 & & & & \multirow[t]{3}{*}{0.92} & \multirow[t]{3}{*}{73.37} \\
\hline $\mathrm{CP} 2$ & $\leftarrow$ & $\mathrm{CP}$ & 0.89 & 0.080 & 9.427 & $* * *$ & & \\
\hline CP3 & $\leftarrow$ & $\mathrm{CP}$ & 0.92 & 0.065 & 10.634 & $* * *$ & & \\
\hline AF1 & $\leftarrow$ & $\mathrm{AF}$ & 0.72 & & & & \multirow[t]{4}{*}{0.86} & \multirow[t]{4}{*}{61.00} \\
\hline AF2 & $\leftarrow$ & $\mathrm{AF}$ & 0.81 & 0.068 & 8.340 & $* * *$ & & \\
\hline AF3 & $\leftarrow$ & $\mathrm{AF}$ & 0.77 & 0.045 & 9.024 & $* * *$ & & \\
\hline AF4 & $\leftarrow$ & $\mathrm{AF}$ & 0.82 & 0.051 & 12.350 & $* * *$ & & \\
\hline $\mathrm{AC} 1$ & $\leftarrow$ & $\mathrm{AC}$ & 0.90 & & & & \multirow[t]{3}{*}{0.93} & \multirow[t]{3}{*}{75.88} \\
\hline $\mathrm{AC} 2$ & $\leftarrow$ & $\mathrm{AC}$ & 0.85 & 0.089 & 12.111 & $* * *$ & & \\
\hline AC3 & $\leftarrow$ & $\mathrm{AC}$ & 0.92 & 0.043 & 14.148 & $* * *$ & & \\
\hline
\end{tabular}

[ ${ }^{\mathrm{a} S e c o n d-o r d e r ~ i n d i c a t o r s, ~}{ }^{\mathrm{b}}$ Second-order factor Notes: The respective indicators of $\mathrm{CP}, \mathrm{AF}$ and $\mathrm{AC}$ are numbered serially (e.g., CP1,CP2, ...AC3)] [Legend: AVE: Average Variance Extracted, CR: Critical Ratio, P: Significance, SE: Standard Estimate, $\left.{ }^{* * *}, \mathrm{p}<0.001\right]$.

Table 2. Discriminant validity of CBE

\begin{tabular}{|l|l|l|l|}
\hline Construct & CP & AF & AC \\
\hline CP & $\mathbf{0 . 8 6}$ & & \\
\hline AF & 0.28 & $\mathbf{0 . 7 8}$ & \\
\hline AC & 0.22 & 0.19 & $\mathbf{0 . 8 7}$ \\
\hline
\end{tabular}

[Note: The numbers in the diagonal line are the average variance extracted by each construct. The numbers above the diagonal show the squared correlation coefficients between the construct.]

In the first stage of the structural equation modeling analyses, the measurement model (CFA) for all proposed constructs was conducted. Therefore, researchers firstly examined the composite reliability for all six constructs: perceived telepresence (PT), social presence (SP), consumer involvement (INV), CBE, word of mouth (WOM), and willingness to donate (WTD) (Fornell and Larcker 1981; Kandemir, Yaprakand and Cavusgil, 2006). All of these constructs were found to have an adequate value of composite reliability (higher than 0.70): PT (0.90), SP (0.88), INV (0.89), CBE (0.89), WOM (0.93) and WTD (0.91) (Hair et al., 1998) (see Table 3). In line with Nunnally (1978), all constructs had a coefficient alpha value higher than 0.70 . All 
items were also noticed to significantly load in their targeted constructs with standardized value above 0.89 (see Table 3). All fit indices related to the measurement model were noticed to be within their recommended level (i.e. $\chi^{2}=757.524, \mathrm{df}=382$, and $\chi^{2} / \mathrm{df}=1.983, \mathrm{CFI}=0.936, \mathrm{GFI}=0.901, \mathrm{TLI}=0.927, \mathrm{IFI}=$ 0.936 and RMSEA $=0.05)(\mathrm{Hu}$ and Bentler, 1999). This implies that the measurement model adequately fit its observed data.

Table 3. Results of the CFA within the six latent factors

\begin{tabular}{|c|c|c|c|c|c|c|c|c|}
\hline Indicator & Direction & Construct & $\begin{array}{c}\text { Standardized } \\
\text { Loading }\end{array}$ & SE & $\mathrm{t}$-value & $\mathrm{P}$ & $\mathrm{CR}$ & AVE \\
\hline CBE1 & $\leftarrow$ & $\mathrm{CBE}$ & 0.70 & & & & \multirow[t]{3}{*}{0.89} & \multirow[t]{3}{*}{66.52} \\
\hline CBE2 & $\leftarrow$ & $\mathrm{CBE}$ & 0.89 & 0.466 & 4.813 & $* * *$ & & \\
\hline CBE3 & $\leftarrow$ & $\mathrm{CBE}$ & 0.85 & 0.510 & 4.826 & $* * *$ & & \\
\hline INV1 & $\leftarrow$ & INV & 0.80 & & & & \multirow[t]{5}{*}{0.89} & \multirow[t]{5}{*}{61.58} \\
\hline INV2 & $\leftarrow$ & INV & 0.76 & 0.074 & 13.014 & $* * *$ & & \\
\hline INV3 & $\leftarrow$ & INV & 0.74 & 0.080 & 10.667 & $* * *$ & & \\
\hline INV4 & $\leftarrow$ & INV & 0.78 & 0.079 & 8.508 & $* * *$ & & \\
\hline INV5 & $\leftarrow$ & INV & 0.84 & .068 & 7.350 & $* * *$ & & \\
\hline PT1 & $\leftarrow$ & PT & 0.82 & & & & \multirow[t]{4}{*}{0.90} & \multirow[t]{4}{*}{68.07} \\
\hline PT2 & $\leftarrow$ & PT & 0.82 & 0.131 & 10.274 & $* * *$ & & \\
\hline PT3 & $\leftarrow$ & PT & 0.84 & 0.129 & 9.894 & $* * *$ & & \\
\hline PT4 & $\leftarrow$ & PT & 0.82 & 0.117 & 9.00 & $* * *$ & & \\
\hline PSI1 & $\leftarrow$ & PSI & 0.82 & & & & \multirow[t]{4}{*}{0.88} & \multirow[t]{4}{*}{65.63} \\
\hline PSI2 & $\leftarrow$ & PSI & 0.81 & 0.072 & 14.752 & $* * *$ & & \\
\hline PSI3 & $\leftarrow$ & PSI & 0.79 & 0.082 & 13.923 & $* * *$ & & \\
\hline PSI4 & $\leftarrow$ & PSI & 0.82 & 0.085 & 11.974 & $* * *$ & & \\
\hline WOM1 & $\leftarrow$ & WOM & 0.88 & & & & \multirow[t]{4}{*}{0.93} & \multirow[t]{4}{*}{76.30} \\
\hline WOM2 & $\leftarrow$ & WOM & 0.87 & 0.092 & 13.678 & $* * *$ & & \\
\hline WOM3 & $\leftarrow$ & WOM & 0.90 & 0.096 & 13.721 & $* * *$ & & \\
\hline WOM4 & $\leftarrow$ & WOM & 0.84 & 0.090 & 11.987 & $* * *$ & & \\
\hline WTD1 & $\leftarrow$ & WTD & 0.86 & & & & \multirow[t]{3}{*}{0.91} & \multirow[t]{3}{*}{71.88} \\
\hline WTD2 & $\leftarrow$ & WTD & 0.87 & 0.097 & 10.919 & $* * *$ & & \\
\hline WTD3 & $\leftarrow$ & WTD & 0.85 & 0.093 & 9.348 & $* * *$ & & \\
\hline
\end{tabular}

[Legend: AVE: Average Variance Extracted, CR: Critical Ratio, P: Significance, $* * *:$ p < 0.001, SE: Standard Estimate].

Based on the values of AVE (50\% as a cut-off point) yielded, researchers examined the discriminant validity of model constructs. Then, the square root of AVE of each construct was compared to the value of the inter-correlation with other corresponding constructs. As seen in Table 4, all exhibited values of the square roots of AVE were higher than all inter-correlations with other corresponding constructs. This, in turn, supports the discriminant validity of model constructs.

Table 4. Discriminant validity of constructs

\begin{tabular}{|l|l|l|l|l|l|l|}
\hline \multirow{2}{*}{ Research Constructs } & \multicolumn{6}{l}{ Correlations } \\
\cline { 2 - 7 } & \multicolumn{1}{|c|}{1} & 2 & 3 & 4 & 5 & 6 \\
\hline 1. CBE & $\mathbf{0 . 8 2}$ & & & & & \\
\hline 2. PT & 0.25 & $\mathbf{0 . 8 3}$ & & & & \\
\hline 3. SPI & 0.15 & 0.38 & $\mathbf{0 . 8 1}$ & & & \\
\hline 4. INV & 0.21 & 0.32 & 0.15 & $\mathbf{0 . 7 8}$ & & \\
\hline 5. WOM & 0.30 & 0.42 & 0.20 & 0.34 & $\mathbf{0 . 8 7}$ & \\
\hline 6. WTD & 0.32 & 0.27 & 0.15 & 0.18 & 0.24 & $\mathbf{0 . 8 5}$ \\
\hline
\end{tabular}

[Note: The figures under the diagonal are the Pearson (R) correlations between the variables. Diagonal elements are square roots of average variance extracted.] 


\section{Common Method Bias}

We conducted a common method bias test to alleviate the issue of common method bias in the sample. We adopted Harman's single-factor test (Harman, 1976) by entering all items from all constructs into an exploratory factor analysis (Podsakoff et al. 2003) and an unrotated factor solution using SPSS. We found that the emerged factor explained $42.9 \%$ of the variance, which is less than $50 \%$. Therefore, our sample does not suffer from the problem of common method bias.

\section{The Structural Model}

According to the main fit indices yielded regarding Model 1, the structural model seems to fit the observed data as all fit indices were noticed to be within their recommended level $(\chi 2=1101.974, \mathrm{df}=391, \chi 2 / \mathrm{df}=2.818 ; \mathrm{CFI}=0.920 ; \mathrm{GFI}=$ 0.915; $\mathrm{AGFI}=0.901 ; \mathrm{TLI}=0.920 ; \mathrm{IFI}=0.930$; and $\mathrm{RMSEA}=0.058)$. The results of the hypothesis testing support all postulated paths for $\mathrm{H} 1-\mathrm{H} 5$. We found that PT was positively associated with $\mathrm{CBE}(\beta=0.28, \mathrm{p}<0.001)$, SP was positively associated with $\operatorname{CBE}(\beta=0.43, p<0.001)$. INV was also associated with $\operatorname{CBE}(\beta=0.59, \mathrm{p}<0.001)$. CBE $\mathrm{R}^{2}=0.61$. Furthermore, we found that CBE positively impacted WOM $(\beta=0.76$, $\mathrm{p}<0.001), \mathrm{R}^{2}=0.61$, and $\mathrm{CBE}$ positively impacted WTD $(\beta=0.41, \mathrm{p}<0.001)$, $\mathrm{R}^{2}=0.51$.Table 5 summarizes the main results.

Table 5. Structural model results.

\begin{tabular}{|l|l|l|l|l|l|}
\hline Hypothesized relationships & $\beta$ & SE & t-value & $\mathrm{P}$ & Result \\
\hline $\mathrm{H} 1: \mathrm{PT} \rightarrow \mathrm{CBE}$ & .28 & .057 & 5.527 & $* * *$ & Supported \\
\hline $\mathrm{H} 2: \mathrm{SP} \rightarrow \mathrm{CBE}$ & .43 & .238 & 7.567 & $* * *$ & Supported \\
\hline $\mathrm{H} 3: \mathrm{INV} \rightarrow \mathrm{CBE}$ & .59 & .084 & 14.167 & $* * *$ & Supported \\
\hline $\mathrm{H} 4: \mathrm{CBE} \rightarrow \mathrm{WOM}$ & .76 & .044 & 15.237 & $* * *$ & Supported \\
\hline $\mathrm{H} 5: \mathrm{CBE} \rightarrow \mathrm{WTD}$ & .41 & .069 & 6.540 & $* * *$ & Supported \\
\hline
\end{tabular}

[Legend: $* * *: p<0.001$, SE: Standard Estimate]

\section{Discussion}

Given the intense competition among non-profit organizations, this study aims to investigate the impact of telepresence, social presence and involvement on CBE, which in turn impacts electronic word of mouth and willingness to donate. Results revealed that telepresence, social presence and involvement are significant antecedents of CBE $\left(\mathrm{R}^{2}=0.061\right)$, which in turn has an impact on electronic word of mouth and willingness to donate.

We adopted Hollebeek et al.'s (2014) scale to measure CBE. Our results confirm that $\mathrm{CBE}$ is a multidimensional construct. Therefore, the CBE scale should reflect cognitive processing, affection and activation constructs. However, we did not measure CBE in this context in the way that previous research (Hollebeek et al., 2014; Leckie et al., 2016) did. We measured it as a second-order construct. We expect that CBE dimensions will enhance donors' engagement with the social media page by 
providing them with more relevant information about the non-profit organization social page activities, create more positive feelings and motivate them to donate.

Therefore, it could be noticed from the second-order analysis (Figure 2) of CBE dimensions that the affection dimension has the strongest impact on creating CBE. This result comes in accordance with previous studies (e.g. Dwivedi; 2015; Thakur, 2016), which measured CBE as a second-order scale. This depicted those consumers who visit the non-profit organizations' Facebook pages to see the progress, for example, of patients' cases to support them emotionally, or poor people who need financial aid for education or food. Furthermore, it highlights the importance for nonprofit organizations to focus on enhancing the emotional involvement of visitors by uploading pictures and videos regarding their support of people and the success stores that they have achieved. Hollebeek et al. (2014, p.154) defined activation as "a consumer's level of energy, effort and time spent on a brand in a particular consumer/brand interaction" (i.e. behavioral CBE dimension). We found that the activation component of CBE emerged as the second-strongest dimension. In other words, the willingness of the non-profit organizations' supporters to spend more time, effort and energy on the brand make them more engaged. This result comes in accordance with Dwivedi's (2015) study which posits that the behavioral component is the second-strongest dimension of $\mathrm{CBE}$, supporting the theory that non-profit organization consumers are investing more time, effort and energy when interacting with the brand. In line with Dwivedi's (2015) study, we find that the cognitive processing component was the third-strongest dimension, implying that the interactions of non-profit consumers with the brand were fully conscious of their thought processing and elaboration.

We find that our results support the relationships between telepresence, social presence, involvement and $\mathrm{CBE}\left(\mathrm{H}_{1}-\mathrm{H}_{3}\right)$. According to the path coefficient analyses, we find that consumer brand involvement is the most significant factor predicting CBE with a coefficient value of 0.59 , which indicates that consumers who are highly involved with a non-profit social media page brand are more likely to demonstrate more engagement. We find that consumer brand involvement is one of the antecedents to formulate $\mathrm{CBE}$; this result comes in accordance with previous research (Dwivedi, 2015; Hollebeek et al., 2014; Leckie et al., 2016). Therefore, we expect that consumers of non-profit organizations should be involved in such Facebook pages and hence this often creates high self-relevance.

Another result shows that the relationship between social presence and CBE comes as the second important path coefficient 0.43 . Therefore, within the context of social media platforms, social presence can be achieved via demonstrating a sense of human warmth and sociability such as stimulating the imagination of interacting with other humans (e.g. pictures of cancer patients). Social presence that is demonstrated by nonprofit organizations with pictures of humans, for example children, women and men who are suffering from different types of misery, and their success stories, reflects a sociable aspect of the non-profit organizations for consumers. This enhanced consumers' engagement with the brand page. Such pictures transmit information through facial expressions, posture and non-verbal cues, and convey a feeling of human warmth, sociability and sensitivity, which positively impact on CBE. Therefore, social presence has a positive impact on CBE. This result is in line with previous research (Cyr et al., 2007; Kietzmann et al., 2012), which asserts the positive 
relationship between social presence and the affective and cognitive aspects of the engagement (i.e. usefulness and enjoyment).

Kietzmann et al. (2012) posit that telepresence within social media (such as Facebook) should be investigated more. Furthermore, the authors call on researchers to further investigate this particular aspect. In the current study, telepresence was found to have the least significant impact on CBE with path coefficient of 0.28 . This result comes in accordance with Mollen and Wilson's (2010) qualitative study, which proposed telepresence as a main antecedent of CBE. Therefore, telepresence as the state of being there is improving itself. As such, consumers of the non-profit organizations' Facebook pages feel like they are transferred to a different world where their body is in one place and their mind is in another (the brand). This result confirms the immersion state that users have when they visit the non-profit organizations' Facebook pages.

We find that CBE is a vital predictor of consumer loyalty (i.e. electronic word of mouth and willingness to donate). In particular, in supporting for hypotheses $\mathrm{H}_{4}$ and $\mathrm{H}_{5}$ we find that $\mathrm{CBE}$ has a strong impact on word of mouth (with path coefficient $0.76, R^{2}=0.61$ ) in comparison to willingness to donate (with path coefficient $0.41, R^{2}$ $=0.51)$. Therefore, it is expected that as consumers have an engagement with the brand (the non-profit organization Facebook page), they start to talk about the brand, like the page, comment (attitudinal loyalty) and eventually donate and ask their friends to do so. This result comes in line with previous research (Dwivedi, 2015; Hollebeek et al., 2014; Leckie et al., 2016; Verhoef et al., 2010).

\section{Implications for Theory}

This research contributes to the field of CBE by presenting a conceptual model that investigates the antecedents and consequences of $\mathrm{CBE}$ on an online social media platform, Facebook. The results confirmed the proposed model through empirical analyses. Hence, the findings of our research demonstrate how CBE is formed in this particular context (based on Hollebeek et al., 2014) and what outcomes are to be expected, which has important implications for both marketing theory and practice.

This research has the following theoretical contribution: (i) the focal construct of this study, CBE, has been shown to be a multidimensional one (i.e. cognition, affection and activation). This result comes in accordance with Hollebeek et al. (2014) and, therefore, our research responds directly to the call of Hollebeek et al.'s (2014) study to make a scale validation and application across different types of online settings and different brands. Our results confirm the previous work of Hollebeek et al. (2014) in regard to the importance of treating the focal construct, $\mathrm{CBE}$, as a multidimensional one. (ii) Hollebeek et al.'s (2014) study tested the impact of the different dimensions of CBE separately based on measuring the impact of consumers' involvement on each of the three dimensions (i.e. affective, cognitive and activation). This study expanded the antecedents of Hollebeek et al.'s (2014) study by investigating the impact of consumer involvement, telepresence and social presence on CBE (second-order). (iii) On the other hand, Hollebeek et al.'s (2014) study re-examine the scale's dimensionality by using a sample of consumers who use the social network LinkedIn, whereas our study focused on Facebook for a non-profit organization. Therefore, this study has shed light on an important sector, in particular by focusing on the 
antecedents of CBE (telepresence, social presence and involvement), which impact the three dimensions of CBE (affective, cognitive and activation), which in turn impact word of mouth and willingness to donate.

\section{Implications for Practice}

According to the EConsultancy (2008), ninety percent of companies agree that online consumer engagement is either "essential" or "important" to their organizations. The results of this study have several managerial implications for non-profit organizations: (i) we find that telepresence, social presence and involvement are the main antecedents of CBE. Therefore, we advise non-profit organizations using Facebook, a social media platform, to properly design their Facebook pages to reflect sensory information and to provide a sense of human warmth (telepresence and social presence). Moreover, we advise non-profit organizations to keep posting and uploading pictures, news, videos and success stories to their pages to increase consumers' involvement. (ii) By employing the notion of $\mathrm{CBE}$ within non-profit organizations' social media platforms, our research provides marketing managers in non-profit organizations with an enhanced understanding of the emerging concept of engagement. CBE with its three dimensions - the cognitive (brand-related thought with consumer/brand interaction), affective (brand-related emotion with consumer/brand interaction) and activation (energy, effort and time spent on consumer/brand interaction) - should be reflected in the design of the Facebook page for non-profit organizations. (iii) Applying all of the above CBE dimensions would eventually enhance relationship marketing (e.g. attitudinal and behavioral loyalty).

\section{Limitations and Future Research}

As any other study, this one has a number of limitations. First, the cross-sectional nature of our data collection provides only a snapshot of CBE with specific brands of non-profit organizations. Second, we developed the conceptual framework based on Hollebeek et al.'s (2014) study. However, future conceptual models may also integrate other antecedent variables (e.g. brand experience, brand personality, brand trust, brand commitment) and consequences variables (e.g. brand equity). Finally, this research investigates the antecedents and consequences of $\mathrm{CBE}$ in a non-profit context in Jordan, Middle East. However, other countries and contexts may not produce the same results. Therefore, our conceptual framework should be validated across a range of contexts and geographic settings.

We did not test CBE directly to corporate level. We used it from customer-centric perspective. Future research is welcome to test our model from an organizational perspective. We encourage future research to test our model using different social media platforms used by non-profit organizations. Previous research (Algharabat and Dennis, 2010a, 2010b, 2010c; Algharabat et al., 2017) employed the notion of authenticity to reflect virtual experience. Therefore, we advise future research to consider authenticity as an antecedent of CBE. Future research may also consider the new definition of virtual product experience, proposed by Algharabat (2014) as an antecedent of $\mathrm{CBE}$. We recommend future research to link $\mathrm{CBE}$ and trust in the context of developing countries (Alalwan et al., 2017b). 


\begin{tabular}{|c|c|}
\hline Construct & Author(s) \\
\hline Perceived telepresence (PT1-PT4) & \multirow{5}{*}{$\begin{array}{l}\text { Coyle and Thorsen } \\
\text { (2001); Klein(2003); } \\
\text { Steuer (1992);Hopkins, } \\
\text { Raymond and Mitra } \\
(2004)\end{array}$} \\
\hline $\begin{array}{l}\text { PT1: While I was browsing the social media page of [Brand X], I felt I was } \\
\text { in the world created by [Brand X] }\end{array}$ & \\
\hline $\begin{array}{l}\text { PT2: While I was browsing the social media page of [Brand X], my mind } \\
\text { was in this room, not in the world created by [Brand X] }\end{array}$ & \\
\hline $\begin{array}{l}\text { PT3: While I was browsing the social media page of [Brand X], my body } \\
\text { was in this room, but my mind was in the world created by [Brand X] }\end{array}$ & \\
\hline $\begin{array}{l}\text { PT4: When I left the social media page of [Brand X], I felt like I came } \\
\text { back to the "real world" after a journey }\end{array}$ & \\
\hline Social Presence (SP1-SP4) & \multirow{5}{*}{$\begin{array}{l}\text { Labrecque }(2014) \\
\text { Rubin, Perse, and } \\
\text { Powell (1985). Gefen } \\
\text { and Straub (2003) }\end{array}$} \\
\hline SP1: [Brand X] makes me feel comfortable, as if I am with a friend & \\
\hline SP2: There is a sense of human contact on [Brand X]; I feel included & \\
\hline SP3: There is a sense of sociability on [Brand X] & \\
\hline SP4: There is a sense of human warmth on [Brand X] & \\
\hline Consumer involvement (INV1- INV4) & \multirow[t]{5}{*}{ Malär et al. (2011) } \\
\hline $\begin{array}{l}\text { INV1: Because of my personal attitudes, I feel that [Brand } \mathrm{X}] \text { is the brand } \\
\text { that ought to be important to me }\end{array}$ & \\
\hline $\begin{array}{l}\text { INV2: Because of my personal values, I feel that }[\text { Brand } X] \text { is the brand } \\
\text { that ought to be important to me }\end{array}$ & \\
\hline INV3: $[\mathrm{Brand} \mathrm{X}]$ is very important to mepersonally & \\
\hline INV4: Compared with other brands, [Brand $\mathrm{X}]$ is important to me & \\
\hline INV5: I'm interested in [Brand X] & \\
\hline CBE “cognitive processing” (CP1-CP4) & \multirow{11}{*}{$\begin{array}{l}\text { Hollebeek, Glynn and } \\
\text { Brodie (2014) }\end{array}$} \\
\hline CP1: Using this brand gets me to think about [Brand X] & \\
\hline CP2: I think about [Brand X] a lot when I'm using it & \\
\hline $\begin{array}{l}\text { CP3: Using this brand stimulates my interest in learning more about } \\
\text { [Brand X] }\end{array}$ & \\
\hline CBE "affection" factor (AF1-AF4) & \\
\hline AF1: I feel very positive when I use [Brand X] & \\
\hline AF2: Using [Brand X] makes me happy & \\
\hline AF3: I feel good when I use [Brand X] & \\
\hline AF4: I'm proud to use [Brand X] & \\
\hline CBE "activation" factor (AC1-AC4) & \\
\hline AC1: I spend a lot of time using [Brand X]compared to other brands & \\
\hline $\begin{array}{l}\text { AC2: Whenever I'm using my non-profit social networking sites, I usually } \\
\text { use [Brand X]. }\end{array}$ & \multirow[t]{4}{*}{$\begin{array}{l}\text { Hollebeek, Glynn and } \\
\text { Brodie (2014) }\end{array}$} \\
\hline AC3: I use [Brand X] the most & \\
\hline Word of Mouth (WOM1-WOM4) & \\
\hline WOM1: I say positive things about [Brand X] to other people & \\
\hline WOM2: I often recommend [Brand X] to others & \multirow{3}{*}{$\begin{array}{l}\text { Leckie et al. (2016); } \\
\text { Zeithaml, Berry, and } \\
\text { Parasuraman(1996) }\end{array}$} \\
\hline WOM3: Sources about [Brand X] are accurate & \\
\hline WOM14: I encourage friends to donate to [Brand X] & \\
\hline Willingness to donate (WTD1- WTD3) & \multirow{4}{*}{$\begin{array}{l}\text { Leckie et al. (2016); } \\
\text { Zeithaml et al. (1996) }\end{array}$} \\
\hline WTD1: I would donate to [Brand X] & \\
\hline WTD2: I would recommend donating tothe cause of [Brand X] & \\
\hline WTD3: [Brand X] will be my first choice to donate to in the future & \\
\hline
\end{tabular}

\section{References}

Abdul-Ghani, E., Hyde, K., and Marshall, R., 2010. Emic and Etic Interpretations of Engagement with a Consumer-to-Consumer Online Auction Site. Journal of Business Research, 64(10), 1060-1066. 
Alalwan, A.A., Dwivedi, Y. K., \& Rana, N. P., 2017b. Factors influencing adoption of mobile banking by Jordanian bank customers: Extending UTAUT2 with trust. International Journal of Information Management, 37(3), 99-110.

Alalwan, AA., Rana, NP., Dwivedi, YK and Algharabat, R., 2017a. Social Media in Marketing: A Review and Analysis of the Existing Literature, Telematics and Informatics (in press)

Algesheimer, R., Dholakia, U.M., and Hermann, A., 2005. The Social Influence of Brand Community: Evidence from European Car Clubs. Journal of Marketing, 69, 19-34.

Algharabat, R. and Dennis, C., 2010a. Using 3D product visualisation for an electrical online retailer. Journal of Customer Behaviour, 9(2), 97-116.

Algharabat, R. and Dennis, C., 2010b. 3D Product authenticity model for online retail: an invariance analysis. International Journal Business Science and Applied Management, 5(3), 14-30.

Algharabat, R. and Dennis, C., 2010c. Modelling the impact of 3D authenticity and 3Dtelepresence on behavioural intention for an online retailer', in Morschett, D., Rudolph, T.,Schnedlitz, P., Schramm-Klein, H. and Swoboda, B. (Eds.): European Retail Research,24(2), 93-109,GablerVerlag, Springer FachmedienWiesbaden.

Algharabat, R., Alalwan, AA., Rana, NP., and Dwivedi, YK., 2017. Three dimensional product presentation quality antecedents and their consequences for online retailers: The moderating role of virtual product experience, Journal of Retailing and Consumer Services. Vol. 36, 203-217

Algharabat, R.S., 2014. Conceptualising and modelling virtual product experience for online retailers. Int. J. Internet Marketing and Advertising, 8(4), 300-319.

Algharabat, R.S. and Shatnawi, T., 2014. The effect of 3D product quality (3D-Q) on perceived risk and purchase intentions: The case of apparel online retailers. Int. J. Electronic Business, 11(3), 262-279.

Anderson, J.C. and Gerbing, D.W., 1988. Structural equation modeling in practice: a review and recommended two-step approach. Psychological Bulletin, 103(3), 411423.

Armstrong, J.S. and Overton, T.S., 1977. Estimating nonresponse bias in mail surveys. Journal of Marketing Research, 16(3), 396-402.

Avnet, T., and Higgins, E.T., 2006a. How Regulatory Fit Affects Value in Consumer Choices and Opinions. Journal of Marketing Research, 43, 1-10.

Avnet, T., and Higgins, E.T., 2006b. Response to Comments on 'How Regulatory Fit Affects Value in Consumer Choices and Opinions. Journal of Marketing Research, 43(1), 24-27.

Beatty, S.E., and Smith, S.M., 1987. External search effort: An investigation across several product categories. Journal of Consumer Research, 14, 83-95.

Biocca, F., 1992. Will simulation sickness slow down the diffusion of virtual environment technology? Presence, 1(3), 334-343. 
Biocca, F. and Nowak, K., 2001. Plugging your body into the telecommunication system. In Lin, C. and Atkin, D. (Eds.), Communication Technology and Society, Hampton Press, Waverly Hill, 407-447.

Bolton, R.N., 2011. Customer Engagement: Opportunities and Challenges for Organizations. Journal of Service Research, 14(3), 272-274.

Bolton, R.N., and Saxena-Iyer, S., 2009. Interactive Services: A Framework, Synthesis and Research Directions. Journal of Interactive Marketing, 23(1), 91-104.

Bowden, J.L., 2009. The Process of Customer Engagement: A Conceptual Framework. Journal of Marketing Theory and Practice, 17(1), 63-74.

Brislin, R., 1986.The Wording and Translation of Research Instruments, in: Field Methods in Cross-Cultural Research. Beverly Hills: W. Lonner and J. Berry, Eds., Sage.

Brodie, R.J., Hollebeek, L., Juric, B., andllic, A., 2011. Customer engagement: Conceptual domain, fundamental propositions, and implications for research. Journal of Service Research, 14(3), 252-271.

Brodie, R.J., Ilic, A., Juric, B., and Hollebeek, L., 2013. Consumer engagement in a virtual brand community: An exploratory analysis. Journal of Business Research, 66(1), 105-114.

Calder, B.J., Malthouse, E.C., and Schaedel, U., 2009. An experimental study of the relationship between online engagement and advertising effectiveness. Journal of Interactive Marketing, 23(4), 321-331.

Chang, Y.-T., Yu, H. and Lu, H-P., 2015. Persuasive messages, popularity cohesion, and message diffusion in social media marketing. Journal of Business Research, 68(4), 777-782.

Cheung, C., Lee, M., and Jin, X., 2011. Customer Engagement in an Online Social Platform: A Conceptual Model and Scale Development. ICIS 2011 Proceedings.

Coupey, E., 2000. Marketing and the Internet: Conceptual Foundation. Upper Saddle River, NJ: Prentice Hall.

Coyle, J,R., and Thorson, E., 2001. The effects of progressive levels of interactivity and vividness in web marketing site. Journal of Advertising, 30(3), 65-77.

Cyr, D., Hassanein, K., Head M., and Ivanov, A., 2007. The role of social presence in establishing loyalty in e-Service environments. Interacting with Computers, 19, 4356.

Dessart, L., Veloutsou, C., and Thomas, A.M., 2016. Capturing consumer engagement: duality, dimensionality and measurement. Journal of Marketing Management, 32(5-6), 399-426.

Deutskens, E., De Ruyter, K., and Wetzels, M., 2006. An assessment of equivalence between online and mail surveys in service research. Journal of Service Research, 8(4), 346-355.

Dormann, C., 2001. Seducing consumers, evaluating emotions. Proceedings of IHMCHI, 10- 14.

Downes, E., and McMillian, S., 2000. Defining interactivity a qualitative identification of key dimensions. Journal of New Media and Society, 2(2), 157-179. 
Dwivedi, A., 2015. A higher-order model of consumer brand engagement and its impact on loyalty intentions. Journal of Retailing and Consumer Services, 24, 100109.

Dwivedi, A., Wilkie, D., Johnson, L. and Weerawardena, J., 2016. Establishing measures and drivers of consumer brand engagement behaviours. Journal of Brand Management, 23(5), pp. 41-69.

Dwivedi, Y.K., Choudrie, J., and Brinkman, W.P., 2006. Development of a survey instrument to examine consumer adoption of broadband. Industrial Management and Data Systems, 106(5), 700-718.

EConsultancy., 2008. Online Customer Engagement Report. Accessed from http://econsultancy.com/reports/online-customer-engagement-report-2008, on $10^{\text {th }}$ April 2017.

Fiore, A.M., Jihyun, K., and Hyun-Hwa, L., 2005. Effect of image interactivity technology on consumer responses toward the online retailer. Journal of Interactive Marketing, 19(3), 38-53.

Fornell, C., and Larcker, D.F., 1981. Evaluating structural equation models with unobservable variables and measurement error. Journal of Marketing Research, 18(1), 39-50.

Fortin, D.R., and Dholakia, R., 2005. Interactivity and vividness effects on social presence and involvement with a web-based advertisement. Journal of Business Research, 58(3), 387-396.

Fulk, J., Schmitz, J. and Power, G.J., 1987. A social information processing model of media use in organizations. Communication Research, 14(5), 520-552.

Gefen, D. and Straub, D., 2003. Managing user trust in B2C e-services. E-Service Journal, 2(2), 7-24.

Hair, J., Anderson, R., Tatham, R. and Black, W., 1998. Multivariate Data Analysis. Prentice-Hall, Upper Saddle River, NJ.

Halaszovich, T., and Nel, F., 2017. Customer-brand engagement and Facebook fanpage "Like"-intention. Journal of Product \& Brand Management, 26(2), 120-134

Hassanein, K. and Head, M., 2006. The impact of infusing social presence in the web interface: An investigation across different products. International Journal of Electronic Commerce, 10(2), 31-55.

Heerink, M., Krose, B., Evers, V., and Wielinga, B., 2008.The influence of social presence on acceptance of a companion robot by older people. Journal of Physical Agents, 2(2), 33-40.

Hepola, J., Karjaluoto, H., and Hintikka, A., 2017. The effect of sensory brand experience and involvement on brand equity directly and indirectly through consumer brand engagement. Journal of Product \& Brand Management, 26(3) 282-293

Hollebeek, L.D., 2011b. Exploring Customer Brand Engagement: Definition and Themes. Journal of Strategic Marketing, 19(7), 555-573.

Hollebeek, L.D., 2011a. Demystifying Customer Brand Engagement: Exploring the Loyalty Nexus. Journal of Marketing Management, 27(7-8), 785-807. 
Hollebeek, L.D., Glynn, M., and Brodie, R., 2014. Consumer Brand Engagement in Social Media: Conceptualization, Scale Development and Validation. Journal of Interactive Marketing, 28, 149-165.

Hollebeek, L.D., Juric, B., and Tang, W., 2017. Virtual brand community engagement practices: A refined typology and model. Journal of Services Marketing, 31(3), 204217.

Hopkins C.D., Raymond M.A., Mitra A., 2004. Consumer responses to perceived telepresence in the online advertising environment: The moderating role of involvement. Marketing Theory, 4(1-2), 137-162.

$\mathrm{Hu}, \mathrm{L}$. and Bentler, P., 1999. Cut-off criteria for fit indexes in covariance structure analysis: conventional criteria versus new alternatives. Structural Equation Modeling, 6(1), 1-55.

Islam, J.U. and Rahman, Z., 2016. Linking customer engagement to trust and wordof-mouth on Facebook brand communities: an empirical study. Journal of Internet Commerce, 15(1), 40-58.

Kandemir, D., Yaprak, A. and Cavusgil, S.T., 2006. Alliance orientation: conceptualization, measurement and impact on market performance. Journal of the Academy of Marketing Science, 34(3), 324-340.

Karson, E.J., and Fisher, R.J., 2005. Predicting intentions to return to the web site: Extending the dual mediation hypothesis. Journal of Interactive Marketing, 19(3), 2 14.

Keller, K.L., 2013. Strategic brand management: Building, measuring and managing brand equity (4th Ed.). Upper Saddle River, NJ: Prentice Hall.

Kietzmann, J.H., Silvestre, B.S., McCarthy, I.P., and Pitt, L.F., 2012. Unpacking the social media phenomenon: Towards a research agenda. Journal of Public Affairs, 12(2), 109-119.

Klein, L., 2003. Creating virtual product experiences: The role of telepresence. Journal of Interactive Marketing, 17(1), 41-55.

Kreijns, K., Kirschner, P., Jochems, W. and Buuren, H., 2004. Determining sociability, social space, and social presence in (a)synchronous collaborative groups. Cyber Psychology \& Behavior, 7(2), 155-172.

Kruikemeier, S., van Noort, G., Vliegenthart, R., and de Vreese, C. H., 2013. Getting closer: The effects of personalized and interactive online political communication. European Journal of Communication, 28(1), 53-66.

Kumar, N. and Benbasat, I., 2002. Para-social presence and communication capabilities of a Web site: A theoretical perspective. e-Service Journal, 1(3), 5-24.

Kumar, V., Aksoy, L., Donkers, B., Venkatesan, R., Wiesel, T., and Tillmanns, S., 2010. Undervalued or Overvalued Customers: Capturing Total Customer Engagement Value. Journal of Service Research,13(3), 297-310.

Kunz, W., Aksoy, L., Bart, Y., Heinonen, K., Kabadayi, S., Ordenes, F.V., Sigala, M., Diaz, D., and Theodoulidis, B., 2017. Customer engagement in a Big Data world.Journal of Services Marketing, 31(2), 161-171.

Laurel, B., 1991. Computers as Theatre. Reading, MA: Addison-Wesley. 
Leckie, C., Nyadzayo, M.W., and Johnson, L.W., 2016. Antecedents of consumer brand engagement and brand loyalty. Journal of Marketing Management, 32(5-6), 558-578.

Leeflang., P., 2011. Paving the Way for Distinguished Marketing. International Journal of Research in Marketing, 28(2), 76-88.

Lii, Y., 2009. A model of customer eloyalty in the online banking. Economics Bulletin, 29(2), 891-902.

Liu, Y. and Shrum, L.J., 2002. What is interactivity and is it always such a good thing? Implications of definition, person, and situation for the influence of interactivity on advertising effectiveness. Journal of Advertising, 31(4), 53-64.

Malär, L., Krohmer, H., Hoyer, W.D., and Nyffenegger, B., 2011. Emotional brand attachment and brand personality: The relative importance of the actual and the ideal self. Journal of Marketing, 75, 35-52.

Malthouse, E. and Hofacker., C., 2010. Looking Back and Looking Forward with Interactive Marketing. Journal of Interactive Marketing, 24(3), 181-184.

Mollen, A., and Wilson, H., 2010. Engagement, Telepresence and Interactivity in Online Consumer Experience. Journal of Business Research, 63(9-10), 919-925.

MSI - Marketing Science Institute., 2014. 2014-2016 Research Priorities. Retrieved from http://www.msi.org/research/index.cfm?id=271.

Nunnally, J.C., 1978. Psychometric Theory, 2nd ed., McGraw-Hill, New York.

O'Brien, I.M. Jarvis, W. and Soutar, G.N., 2015. Integrating social issues and customer engagement to drive loyalty in a service organisation. Journal of Services Marketing, 29(6/7), 547-559.

Passikoff R, Keys B, Schultz DE., 2007. C-MEEs: Cross-media engagement evaluations. ADMAP, 487, 31.

Patterson, P., Ting, Y., and De Ruyter, K., 2006. Understanding Customer Engagement in Services. Brisbane. AZMAC Proceedings.

Pham, Michel T. and Tamar Avnet., 2009. Rethinking Regulatory Engagement Theory. Journal of Consumer Psychology, 19(2), 115-123.

Phillips, B.J. and McQuarrie. E.F., 2010. Narrative and Persuasion in Fashion Advertising. Journal of Consumer Research, 37(3), 368-392.

Phua, J. and Ahn, S.J., 2016. Explicating the 'like' on Facebook brand pages: the effect of intensity of Facebookuse, number of overall 'likes', and number of friends' 'likes'on consumers' brand outcomes. Journal of Marketing Communications, 22(5), 544-559.

Pongpaew, W., Speece, M., and Tiangsoongnern, L., 2017. Social presence and customer brand engagement on Facebook brand pages. Journal of Product \& Brand Management, 26(3), 262-281

Rice, R.E., and Case, D., 1983. Electronic message systems in the university: A description of use and utility. Journal of Communications. 33(1), 131-152.

Schau, H.J., Muñiz A.M, Arnould, E.J., 2009. How Brand Communities Create Value. Journal of Marketing, 73(5), 30-51.

Short, J., Williams, E. and Christie, B., 1976. The Social Psychology of Telecommunications, Wiley, London. 
Sivadas, E. and Jindal, R.P., 2017. Alternative measures of satisfaction and word of mouth. Journal of Services Marketing, 31(2), 119-130,

Slater M., 1999. Measuring presence: a response to the Witmer and Singer presence questionnaire. Presence, 8(5), 560-565.

Sprott, D., Czellar, S., and Spangenberg, E., 2009. The Importance of a General Measure of Brand Engagement on Market Behavior: Development and Validation of a Scale. Journal of Marketing Research, 46(1), 92-104.

Sproull, L., and Kiesler, S., 1986. Reducing social context cues: The case of electronic mail. Management Science, 32, 1492-1512.

Steuer, J., 1992. Defining virtual reality: Dimensions determining telepresence. Journal of Communication, 42(4), 73-93.

Straub, D.W., 1994. The effect of culture on IT diffusion: E-mail and FAX in Japan and the U.S. Information Systems Research,5(1),23-47.

Straub, D.W., and Karahanna, E., 1998. Knowledge worker communications and recipient availability: Toward a task closure explanation of media choice. Telecommunications, Wiley, London.

Tafesse, W., 2016. An experiential model of consumer engagement in social media. Journal of Product \& Brand Management, 25(5), 424-434.

Thakur, R., 2016. Understanding Customer Engagement and Loyalty: A Case of Mobile Devices for Shopping. Journal of Retailing and Consumer Services, 32, 151163.

Thomson, M., MacInnis, D.J, Park, C.W., 2005. The ties that bind: measuring the strength of consumers' emotional attachments to brands. Journal of Consumer Psychology, 15(1), 77-91.

van der Heijden, H., Verhagen, T., and Creemers, M., 2003. Understanding online purchase intentions: contributions from technology and trust perspectives. European Journal of Information Systems, 12, 41-48.

Van Doorn, Jenny, Katherine N. Lemon, Vikas Mittal, Stephan Nass, DoreenPeck, Peter Pirner, and Peter C. Verhoef., 2010. Customer Engagement Behavior: Theoretical Foundations and Research Directions. Journal of Service Research, 13(3), 253-266.

Verhoef, P.C., Reinartz, W.J., and Krafft, M., 2010. Customer Engagement as a New Perspective in Customer Management. Journal of Service Research, 13(3), 247-252. Vivek, S.D., Beatty, S.E., and Morgan, R.M., 2012. Customer engagement: Exploring customer relationships beyond purchase. The Journal of Marketing Theory and Practice, 20(2), 122-146.

Vivek, S.D., Beatty, S.E., Dalela, V., and Morgan, R.M., 2014. A generalized multidimensional scale for measuring customer engagement. The Journal of Marketing Theory and Practice, 22(4), 401-420.

Weiner, M., and Mehrabian, A., 1968. Language within language: Immediacy, a channel in verbal communication. Appleton-Centry-Crofts, New York, NY.

Wirtz, J., Den Ambtman, A., Bloemer, J., Horváth, C., Ramaseshan, B., van de Klundert, J., Aksoy, L., 2013. Managing brands and customer engagement in online brand communities. Journal of Service Management, 24(3), 223-244. 
Witmer BG, Singer MJ., 1998. Measuring presence in virtual environments: A presence questionnaire. Presence, 7(3), 225-240.

Yap, S.F.C. and Lee, C.K.C., 2014. Leveraging the power of online social networks: a contingency approach. Marketing Intelligence \& Planning, 32(3), 345-374.

Yoo, Y., and Alavi, M., 2001. Media and group cohesion: Relative influences on social presence, task participation, and group consensus. MIS Quarterly, 25(3), 371390.

Zaichkowsky, J.L., 1985. Measuring the involvement construct. Journal of Consumer Research, 12, 341-352.

Zeithaml, V.A., Berry, L.L., and Parasuraman, A., 1996. The behavioral consequences of service quality. Journal of Marketing, 60(2), 31-46. 